\title{
European Social Science History Conference
}

\author{
Alan Draper \\ St. Lawrence University \\ Philip Scranton \\ Rutgers University, Camden
}

The first European Social Science History Conference was held in Noordwijkerhout, the Netherlands on May 9-11, 1996. The Conference was organized by the International Institute of Social History and modeled on conferences hosted by the American Social Science History Association. Panels were organized into networks, covering such topics as Family Strategies and Changing Labor Relations; Labor; Nations and Nation-Building; Political Movements; and Women/Gender, among others. Scholars in these fields convened under the direction of a network chair during the conference and were encouraged to exchange and develop their ideas between conferences, which are scheduled to be held biannually.

One session on "Labor Relations and Worker Militancy" included papers by Eric Nijhof (Utrecht University) and Kristian Falk (Stockholm University). Nijhof's paper offered an interesting comparison of union organization among dockworkers in Hamburg, Le Havre, London, and Rotterdam at the turn of the century. Nijhof found that union organization was highly unstable in each port, rising and falling with the outcome of each strike. Falk's paper examined forest workers in Sweden who organized an unusually successful and durable revolutionary syndicalist union. At its peak, according to Falk, the union had 30,000 members, achieved higher wages for its members than a competing reformist union, and was the only syndicalist union in Sweden to survive after World War Two.

Another panel examined state and trade union responses to immigration. Amsterdam University was well represented by Louise Reitbergen and $\mathbf{J}$. Roosblad. Both presented papers examining the response of Dutch trade unions to immigrant workers in the Netherlands. Simone Goedings (European Institute) offered a fascinating background to current efforts to deregulate labor markets in Europe. She traced these efforts back to the 1950 s, when Italy tried to export its unemployment to the other members of the Common Market.

Two intriguing papers were presented at a panel on "Determinants 
of Working-Class Formation." Willfried Spohn (Free University, Berlin) presented an ambitious but schematic theory that attributed different working-class trajectories to the role religion played within working-class communities. The paper by Peter de Vries (Tel Aviv University) was both provocative and nuanced. He described how lsraeli clerks in the 1950s appropriated robust, manly symbols to describe their own contribution to the Zionist project of state building. If prevailing Zionist imagery portrayed agricultural workers as soldiers on the front lines of state building, then clerks wanted to be perceived as soldiers laboring on the home front whose contribution was no less important to the national project.

Two panels at the conference considered the welfare state. One session presented work in progress on the development of the welfare state by a team of historians and sociologists at Stockholm University led by Walter Korpi. Response from the audience to the panel was brisk. Presentations left the impression that sociologists had triumphed over historians within the research team and that the team's tight focus on social insurance programs was capricious and would miss the different forms compensation for workers can take.

A second panel on "Transformations of Welfare State Regimes" proceeded historically. Annika Akerblom (Uppsala University) argued that the female factory inspectorate in Sweden was composed of middle-class women whose investigations of social conditions among working women created the knowledge base for emerging social policy. Kristen Stromberg (University of Pennsylvania) presented fascinating material on "The Development of French Family Policy in the 1930s and 1940s." Stromberg's paper took issue with the prevailing view that the French state imperiously extended its authority into every domain. Rather, Stromberg contends, the French state had to muscle for space with pronatalist organizations which were so intent on creating an enhanced role for themselves that the state was often reduced to a mere arbiter among them. Finally, K. Van Kersbergen (Amsterdam University) brought the panel's discussion of the welfare state into the present period. He forecast that the contemporary welfare state will continue to be anchored at the level of the national state, despite the challenges economic globalization and political integration pose to it.

In a session on labor markets and movements and the impact of state policies, Jin-Fen Chan (Academic Sinica, Taiwan) opened with a review of the disastrous Eastern Airlines machinists' strike of the late 1980s. Providing a background history of the airline's descent into economic crisis and Frank Lorenzo's takeover, Chan argued that external factors (deregulation and a climate of fierce management assertiveness) played a major role in this "no winners" conflict. Other related issues included a hostile political environment under the Reagan Administration and a lack of public support for the machinists, which she treated as factors "internal" 
to the union's struggle. Questions in discussion challenged this externalinternal dichotomy and invited Chan to examine union history for a clearer view of the machinists' strategies and to survey earlier court and National Labor Relations Board decisions that limited labor's tactical options at the time.

Alan Draper (St. Lawrence University) followed with "The Long Shadow of the American South," which introduced European attendees to the regional complexities that thwarted union efforts to create socialdemocratic policies in the decades after World War Two. Draper argued that the Democratic party's expectation that black enfranchisement would nationalize and rationalize economic relations in the South proved unrealistic, as southern whites instead moved to the Republican party to sustain their durable position as an antiunion, racist, and deeply conservative subnational polity. As Democrats elected to Congress gradually became more liberal and nationally sensitive, "new" Republicans reinvigorated the "spirit" of the old southern resistance to social change. Now Republican presidential candidates can rely on 100 electoral votes or more from the South, ironically expressing the more clearly polarized party system that union activists sought in the postwar years, yet with ambiguous implications given the wider ideological shifts that the Reagan years have brought.

Last, Haia Shpaya-Makov (Haifa University), focusing on late nineteenth-century British workers, argued for greater attention to publicsector workers, who have long been relatively ignored by labor historians. Both the large numbers and the newly defined occupational positions of government employees, whose jobs also lacked customary labor relations practices, mark public-sector workers as worthy of attention. ShpayaMakov showed how post-1860s military-style discipline yielded massive turnover in the English police force. Continuing worker protests forced policy revisions that sharply reduced dismissals by 1880 ; an 1890 pension plan authorized by Parliament (which granted paid retirement after twenty-five years of service) further stabilized police staffs and augmented professionalization. Questioners asked the author to elaborate the historiographical reasons for researchers' bypassing of public-sector employees and to examine relative wage profiles for police and other modestly skilled trades as a contextual check on turnover patterns.

The inaugural European Social Science History Conference was a success in its ability to attract papers across a broad range of themes and topics. But its strength was also its weakness. Panels were not well integrated and were permeated by a sense of diffuseness. Perhaps if networks of scholars organized at the conference become fully operational this problem will be solved by the time of the next conference, which is scheduled for spring 1998 in Amsterdam. 